\title{
Effect of Web-Based She Smart Education Models on Adolescent Girl's Knowledge, Attitudes, and Practice about Obesity
}

\author{
A. Herliah \\ Midwifery Study Program, Graduate School of Hasanuddin University, Makassar, Indonesia \\ Corresponding author email: herliaha19p@student.unhas.ac.id
}

Yusring Sanusi Baso

Learning Media Center, Learning Resource and E-Learning, Hasanuddin University, Makassar, Indonesia

Email: yusring@unhas.ac.id

\section{Healthy Hidayanty}

Department Of Nutrition Sciences, Faculty of Public Health, Hasanuddin University, Makassar, Indonesia

Email: hhidayanty@yahoo.com

\section{Syafruddin Syarif}

Department of Electrical Engineering, Faculty of Engineering, Hasanuddin University, Makassar, Indonesia

Email: syafruddin.s@eng.unhas.ac.id

\author{
Aminuddin \\ Department of Nutrition, Faculty of Medicine, Hasanuddin University, Makassar, Indonesia \\ Email: aminuddin@med.unhas.ac.id

\section{Burhanuddin Bahar} \\ Department Of Nutrition Sciences, Faculty of Public Health, Hasanuddin University, Makassar, Indonesia \\ Email: baharburhanuddin96@gmail.com
}

\begin{abstract}
Obesity is a disorder characterized by excessive accumulation of body fat. The nutritional impact is more than just disturbing the aesthetics of appearance. Obesity (overweight and overweight) is a new chronic disorder that soon becomes a global pandemic that is quite difficult to control. To improve the knowledge, attitudes, and Practice of Adolescent Girls about obesity. Use Pre-Experiment with one group pre-test and post-test design. Sampling technique using purposive sampling and obtained a total of 47 respondents. The research was conducted in the Senior High School of 12 Makassar in September-October 2021. Data analysis using the McNemar test. The results of statistics showed that there is an influence on the use of the web-based She Smart education model of the knowledge and attitudes of Adolescent Girls with a value of p-value $=0.008(p<0.05)$. And there was no influence on the use of the web-based She Smart education model on the Practice of Adolescent Girls with a p-value of 0.453 $(p>0.05)$. There is an influence on providing obesity education before and after intervention through web-based obesity education media in improving knowledge and attitudes but does not affect the Practice of adolescent girls in overcoming the problem of obesity.
\end{abstract}

Keywords---adolescent girls, behavior, education, obesity, web-based. 
Introduction

Obesity is a common problem that children experience today. Obesity is a disorder characterized by excessive accumulation of body fat, nutritional impact is more than just disturbing the aesthetic appearance (Nirvana, 2012). Adolescence is a transition period between childhood and adulthood, during which social and psychological changes occur that affect social behavior (Andrade et al., 2019).

According to the World Health Organization (WHO), adolescents (adolescence) are those aged10-19 years. The United Nations says youth are young for ages 15-24. It is united in the terminology of young people who include the ageof 10-24 years (Abrori, 2017). The prevalence of obesity in adolescents aged 13-15 years in Indonesia was 10.8\% in 2013 and increased to 16\% in 2018 (Kementerian Kesehatan RI, 2018).

Based on data from the South Sulawesi Provincial Health Office, shows that there is an increase in obesity cases in adolescents from year to year. The number of adolescents who were obese in 2015 was 36.542 people, increased in 2016 as many as 68.792 people, and increased again in 2017 as many as 122.906 people (Dinkes Prov. Sulawesi Selatan, 2017).

Obesity in adolescence has an impact on health in adulthood, such as type 2 diabetes, hypertension, severe obesity, kidney dysfunction, and mobility limitations (Pinho \& Prange, 2016). Adolescents who suffer from overweight are at as much as $70 \%$ risk of suffering from obesity in adulthood (Niswah et al., 2017). According to Adebimpe (2019), it is suggested that about 3.8\% of adolescents are overweight $(2.1 \%)$ or obese $(1.7 \%)$ of which about $32.9 \%$ have fewer knowledge scores about obesity risk factors. The results showed a link between knowledge and the incidence of obesity, but age and physical activity were most dominant in leading to obesity (Moriconi et al., 2020). Lack of knowledge results in a person often experiencing obesity due to ignorance about the correct means of prevention, so the importance of educational initiatives aimed at overcoming the knowledge gap (O'Keeffe et al., 2020).

In recent years, many Electronic Health (e-health and mobile Health (mHealth) solutions have been implemented and successfully implemented by leveraging the latest computing technologies and strong mobile advances. Such solutions offer many levels of service to users and a huge intensity of interaction including data exchange, information retrieval, and user feedback details. Improving health care outcomes requires appropriate solutions that will facilitate the improvement of medical care outcomes (Alloghani et al., 2016).

In the current era of globalization, the development of technology is increasingly advanced and smartphone or smartphone users are increasing. Smartphones have several features that can be tailored to the needs of their users, including in obtaining health information. Web-based learning media is one of the web-based education services that enable edutainment by utilizing internet media. E-learning significantly affects the knowledge system (Huang \& Zhao, 2020; Frischknecht \& Rebitzer, 2005). E-learning is becoming the latest trend in the world of education because its use can exceed the limits of space and time, so it is not uncommon for electronic-based learning to be judged up to date (Evans, 2008; Wu et al., 2013). The existence of the internet allows distance learning that not only transmits information but also creates a real-time learning environment. One form of internet network use in distance learning is the creation of web-based learning (Arianggara et al., 2021).

Therefore, an information system that can help adolescents to get access to information about the problem of obesity in Adolescent Girls can be accessed via desktop or mobile phone that does not require certain qualifications or types of mobile phones, large storage capacity and can be reached by everyone (de Siqueira et al., 2020). The program is designed as an E-Learning model that can educate adolescents in web-based obesity prevention (Hernández-Garduño, 2020). Based on the background above, this study aims to improve the knowledge, attitudes, and Practice of Adolescent Girls about obesity (Schinke et al., 2008; Miller \& Gur, 2002).

\section{Research Methods}

This research uses the Pre-experimental Design method with the type of design used by One Group Pretest-Posttest Design. The research was conducted in Senior High School 12 Makassar in September-October 2021 after getting ethical clearance from the ethics committee of the Faculty of Public Health, Hasanuddin University Makassar with the number $7402 / \mathrm{UN} 4.14 .1 / \mathrm{TP} .01 .02 / 2021$. The population in this study was all Adolescent Girls class XI in Senior High School in 12 Makassar which amounted to 152 people. The sampling technique in this study is Purposive Sampling. The sample in the study was 47 students. Obtained by using the formula loving. Data retrieval techniques are a way to obtain data that supports research achievement. Data collection is done using primary data and secondary data. Primary data are obtained directly from Adolescent Girls to get respondent data (Neumark-Sztainer et al., 1998). Secondary data are obtained from school reports. Computerized data processing using the SPSS program version 21 . Analyze the data using the McNemar test. 


\section{Result and Discussion}

Knowledge

Table 1

The Effect of She Smart Education Based WEB on Adolescent Girls Knowledge of Obesity $(\mathrm{n}=47)$

\begin{tabular}{|c|c|c|c|c|c|c|c|}
\hline \multirow{3}{*}{$\begin{array}{l}\text { Pre } \\
\text { Test }\end{array}$} & \multicolumn{6}{|c|}{ Post Test } & \multirow{3}{*}{$P$} \\
\hline & \multicolumn{2}{|c|}{ Good } & \multicolumn{2}{|c|}{ Less } & \multicolumn{2}{|c|}{ Total } & \\
\hline & $\mathrm{n}$ & $\%$ & $\mathrm{~N}$ & $\%$ & $\mathrm{n}$ & $\%$ & \\
\hline Less & 8 & 17,02 & 0 & 0 & 8 & 17,02 & \\
\hline Good & 39 & 82,98 & 0 & 0 & 39 & 82,98 & 0,008 \\
\hline Total & 47 & 100 & 0 & 0 & 47 & 100 & \\
\hline
\end{tabular}

* McNemar test

The results of statistical tests on table 1 showed that after the intervention, adolescents who experienced a change in knowledge from the category were less to good as many as 8 people (17.02\%), good categories to less non-existent. Then students who had good knowledge before the intervention and did not experience changes after intervention as many as 39 people $(82.98 \%)$. So the number of students who have good knowledge as many as 47 people (100\%) and who have less knowledge do not exist. Based on the results of the statistical test obtained the value $p=0.008$ $(\mathrm{p}<0.05)$ then $\mathrm{HO}$ is rejected. And it can be concluded that there is an influence of knowledge before and after the provision of obesity education using Web-based She Smart in Adolescent Girls (Farooqui et al., 2018).

\section{Attitude}

Table 2

Influence of She Smart Education Based WEB on Adolescent Girls' Attitudes about Obesity $(\mathrm{n}=47)$

\begin{tabular}{|c|c|c|c|c|c|c|c|}
\hline \multirow{3}{*}{$\begin{array}{l}\text { Pre } \\
\text { Test }\end{array}$} & \multicolumn{6}{|c|}{ Post Test } & \multirow{3}{*}{$P$} \\
\hline & \multicolumn{2}{|c|}{ Good } & \multicolumn{2}{|c|}{ Less } & \multicolumn{2}{|r|}{ Total } & \\
\hline & $\mathrm{N}$ & $\%$ & $\mathrm{~N}$ & $\%$ & $\mathrm{n}$ & $\%$ & \\
\hline Less & 8 & 17,02 & 0 & 0 & 8 & 17,02 & \\
\hline Good & 39 & 82,98 & 0 & 0 & 39 & 82,98 & 0,008 \\
\hline Total & 47 & 100 & 0 & 0 & 47 & 100 & \\
\hline
\end{tabular}

* McNemar test

The results of statistical tests in table 2 showed that after the intervention, adolescents who experienced a change in attitude from a lesser category to as many as 8 people (17.02\%), a good category to less none. Then students who had a good attitude before the intervention and did not experience changes after intervention as many as 39 people $(82.98 \%)$. So the number of students who have a good attitude as many as 47 people (100\%) and who have a less attitude is not there. Based on the results of the statistical test obtained the value $\mathrm{p}=0.008(\mathrm{p}<0.05)$ then $\mathrm{H} 0$ is rejected. And it can be concluded that there is an influence of attitude before and after the provision of obesity education using Web-based She Smart in Adolescent Girls.

Practice

Table 3

Effect of She Smart Education-Based Education WEB on Adolescent Girls Practice on Obesity $(\mathrm{n}=47)$

\begin{tabular}{lccccccc}
\hline \multirow{2}{*}{$\begin{array}{l}\text { Pre } \\
\text { Test }\end{array}$} & \multicolumn{9}{c}{ Post Test } & \multirow{2}{*}{$P$} \\
\cline { 2 - 6 } & \multicolumn{2}{c}{ Positive } & \multicolumn{2}{c}{ Negative } & \multicolumn{2}{c}{ Total } & \\
\hline Negative & 5 & 10,64 & $\mathrm{~N}$ & $\%$ & $\mathrm{~N}$ & $\%$ & \\
Positive & 37 & 78,72 & 2 & 4,26 & 39 & 51,1 & \multirow{2}{*}{0,453} \\
Total & 42 & 89,36 & 5 & 10,64 & 47 & 100 & \\
\hline
\end{tabular}

* McNemar test 
The statistical test in table 3 showed that after the intervention, adolescents who experienced a change in action from negative to the positive category as many as 5 people $(10.64 \%)$, positive to the negative category as many as 2 people (4.26\%). Then the students who had positive Practice before the intervention and did not experience changes after intervention as many as 37 people $(78.72 \%)$. So the number of students who have positive Practice as many as 42 people (89.36\%) and who have negative Practice as many as 5 people (10.64\%). Based on statistical test results obtained the value $\mathrm{p}=0.453$ ( $\mathrm{p}>0.05)$ then $\mathrm{H} 0$ is accepted. And it can be concluded that there is no effect of action before and after the provision of obesity education using Web-based She Smart in Adolescent Girls.

\section{The influence of the use of obesity education using Web-based She Smart on the knowledge of adolescent girls}

Health education is a way to support health programs that can produce changes and increases in knowledge in a short time. In this case, health education can help the learning process in individuals, groups, or communities from not knowing about health values to knowing, from being unable to overcome health problems to being able (Utari et al., 2014). The study found that web-based obesity education of Adolescent Girls is worth using and has the potential to be developed in increasing knowledge in Adolescent Girls. This is in line with the results of research (Nur, 2018) that most teenagers use the internet to search for health information.

This study found that there was a difference in the knowledge of Adolescent Girls before and after being given a web-based obesity education, media there was an increase with a value of $p$-value 0.008 ( $p<0.05)$, it can be concluded that web-based obesity education media is very significant in increasing the knowledge of Adolescent Girls. This is in line with the research Aldera et al. (2021), this web-based board game application has a difference in knowledge before and after being educated through board game media. This media board game can increase adolescent knowledge about the problem of obesity. The education on obesity in adolescent girls is expected to have a positive impact in increasing public awareness, especially Adolescent Girls to do something that can prevent the occurrence of obesity in adolescence. If the young woman already knows then with that knowledge she will have used the material he has learned to prevent obesity (Ernawati et al., 2022).

\section{Influence of obesity education uses using Web-based She Smart on the attitudes of adolescent girls}

Attitudes are used as predictors of behavior that is a person's response when receiving a stimulus from his or her environment. Attitude is something inherent in the beliefs and feelings towards an object and a predisposition to acting toward the object in certain ways (Saam, 2013).

This study found differences in the attitude of Adolescent Girls before and after being given a web-based obesity education media with a value of $p$-value 0.008 ( $p<0.05)$, it can be concluded that web-based obesity education media is very significant in improving the attitude of Adolescent Girls. This is in line with research conducted by Gemini \& Natalia (2021), which shows that providing obesity education through mobile health effectively helps change healthy living behaviors of obese children and can be applied in Indonesia, especially for the scope of the health of obese children in the form of educational interventions in healthy living (Porges, 2003; Benjamini et al., 2001).

This study implies that it makes it easier to study obesity material and is proven to increase the change in attitudes of Adolescent Girls so that the web is considered worthy and effective as an educational medium. Because health education can play a role to change the attitudes of individuals, groups, and communities by health values. The expected change in attitude is to be able to maintain and improve health, prevent the risk of getting sick, protect yourself from the threat of disease.

\section{The influence of the use of obesity education using Web-based She Smart on the practice of adolescent girls}

Practice is Practice that is done with a specific purpose and purpose and a specific purpose that is known or obtained through the learning process. In the field of health action is an activity to prevent a health problem/disease. The study found no difference in the Practice of Adolescent Girls before and after. Being given a web-based obesity education, media with a $p$-value of $0.453(p>0.05)$, it can be concluded that web-based obesity education, media has no significant influence in improving the Practice of adolescent girls. This is in line with research conducted by ASSIDHIQ (2019), which shows that there is no significant influence on nutritional education media on students' Practice. The availability of Web-based She Smart for obesity education in Adolescent Girls can have a positive impact in raising public awareness, especially Adolescent Girls to prevent obesity independently. 


\section{Conclusion}

Based on the results of research and data analysis conducted by researchers, it can be concluded that there is an influence on providing obesity education before and after intervention through web-based obesity education media in improving knowledge and attitudes but has no effect on the Practice of Adolescent Girls in overcoming the problem of obesity.

\section{Acknowledgments}

The researcher would like to express her thankfulness to all the staff and lecturers who helped the researcher by permitting her to do her research from September to October 2021 toward the student SMA Negeri 12 Makassar.

\section{References}

Abrori, Q. M. (2017). Buku Ajar Infeksi Menular Seksual. Pontianak: Universitas Muhammadiyah Pontianak.

Adebimpe, W. O. (2019). Prevalence and knowledge of risk factors of childhood obesity among school-going children in Osogbo, south-western Nigeria. Malawi Medical Journal, 31(1), 19-24.

Aldera, A., Marbun, R. M., Atmasumarta, T., \& Marzuki, M. A. A. A. F. (2021). Daya Terima Media Board Game Dan Perbedaan Pengetahuan Remaja Sebelum Dan Sesudah Diberikan Edukasi Gaya Hidup Cegah Obesitas Di Komunitas Board Game Jakarta. Kocenin Serial Konferensi (E) ISSN: 2746-7112, 2(1), 2-1.

Alloghani, M., Hussain, A., Al-Jumeily, D., Fergus, P., Abuelma'Atti, O., \& Hamden, H. (2016). A mobile health monitoring application for obesity management and control using the internet-of-things. In 2016 Sixth International Conference on Digital Information Processing and Communications (ICDIPC) (pp. 19-24). IEEE.

Andrade, V., de Santana, M. L., Fukutani, K. F., Queiroz, A. T., Arriaga, M. B., Conceição-Machado, M. E. P., ... \& Andrade, B. B. (2019). Multidimensional analysis of food consumption reveals a unique dietary profile associated with overweight and obesity in adolescents. Nutrients, 11(8), 1946.

Arianggara, A. W., Baso, Y. S., Ramadany, S., Manapa, E. S., \& Usman, A. N. (2021). Web-based competency test model for midwifery students. International Journal of Health \& Medical Sciences, 4(1), 1-7.

ASSIDHIQ, M. R. (2019). Pengaruh Edukasi Gizi Dengan Media E-Booklet Terhadap Pengetahuan, Sikap, Perilaku Makan Dan Berat Badan Tentang Upaya Pencegahan Obesitas Pada Remaja Di SMA Negeri Semarang.

Benjamini, Y., Drai, D., Elmer, G., Kafkafi, N., \& Golani, I. (2001). Controlling the false discovery rate in behavior genetics research. Behavioural brain research, 125(1-2), 279-284. https://doi.org/10.1016/S01664328(01)00297-2

de Siqueira, J. V. V., Almeida, L. G., Zica, B. O., Brum, I. B., Barceló, A., \& de Siqueira Galil, A. G. (2020). Impact of obesity on hospitalizations and mortality, due to COVID-19: a systematic review. Obesity research \& clinical practice. https://doi.org/10.1016/j.orcp.2020.07.005

Dinkes Prov. Sulawesi Selatan. (2017). Profil kesehatan Provinsi Sulawesi Selatan tahun 2017. Dinas Kesehatan Sulawesi Selatan.

Ernawati, E., Baso, Y. S., Hidayanty, H., Syarif, S., Aminuddin, A., \& Bahar, B. (2022). The effects of anemia education using web-based she smart to improve knowledge, attitudes, and practice in adolescent girls. International Journal of Health \& Medical Sciences, 5(1), 44-49. https://doi.org/10.21744/ijhms.v5n1.1831

Evans, C. (2008). The effectiveness of m-learning in the form of podcast revision lectures in higher education. Computers \& education, 50(2), 491-498. https://doi.org/10.1016/j.compedu.2007.09.016

Farooqui, N., Bansal, A., \& Agarwal, A. K. (2018). Impact of financial aid as scholarships on educational attainment \& quality of life among Muslim adolescent girls in madrasas. International Journal of Health \& Medical Sciences, 1(1), 1-9. https://doi.org/10.31295/ijhms.v1n1.33

Frischknecht, R., \& Rebitzer, G. (2005). The ecoinvent database system: a comprehensive web-based LCA database. Journal of Cleaner Production, 13(13-14), 1337-1343. https://doi.org/10.1016/j.jclepro.2005.05.002

Gemini, S., \& Natalia, R. (2021). Aplikasi Mobile Health Sebagai Intervensi Promosi Gaya Hidup Sehat Mencegah Obesitas Anak: Kajian Literatur. Jurnal Kesehatan Mercusuar, 4(1), 38-47.

Hernández-Garduño, E. (2020). Obesity is the comorbidity more strongly associated for Covid-19 in Mexico. A case-control study. Obesity research \& clinical practice, 14(4), 375-379. https://doi.org/10.1016/j.orcp.2020.06.001

Huang, Y., \& Zhao, N. (2020). Generalized anxiety disorder, depressive symptoms and sleep quality during COVID19 outbreak in China: a web-based cross-sectional survey. Psychiatry research, 288, 112954. https://doi.org/10.1016/j.psychres.2020.112954

Kementerian Kesehatan RI. (2018). Riskesdas 2018. Laporan Nasional Riskesndas 2018, 44(8), 181-222. 
Miller, L., \& Gur, M. (2002). Religiousness and sexual responsibility in adolescent girls. Journal of Adolescent Health, 31(5), 401-406. https://doi.org/10.1016/S1054-139X(02)00403-2

Moriconi, D., Masi, S., Rebelos, E., Virdis, A., Manca, M. L., De Marco, S., ... \& Nannipieri, M. (2020). Obesity prolongs the hospital stay in patients affected by COVID-19, and may impact on SARS-COV-2 shedding. Obesity research \& clinical practice, 14(3), 205-209. https://doi.org/10.1016/j.orcp.2020.05.009

Neumark-Sztainer, D., Story, M., \& Faibisch, L. (1998). Perceived stigmatization among overweight AfricanAmerican and Caucasian adolescent girls. Journal of Adolescent Health,23(5), 264-270. https://doi.org/10.1016/S1054-139X(98)00044-5

Nirvana, A.B. (2012). Childhood obesity and its prevention are supplemented with nutrition for children. Nuha Medika.

Niswah, S. R., Soemanto, R. B., \& Murti, B. (2017). Factors associated with overweight and obesity in adolescents in Kartasura, Central Java. Journal of Health Promotion and Behavior, 2(3), 207-217.

Nur, L. (2018). Gambaran Penggunaan Internet dalam Mencari Informasi Kesehatan Pada Siswa Sekolah Menengah Pertama (SMP) X. Jurnal Promkes: The Indonesian Journal of Health Promotion and Health Education, 6(2), 188-200.

O'Keeffe, M., Flint, S. W., Watts, K., \& Rubino, F. (2020). Knowledge gaps and weight stigma shape attitudes toward obesity. The Lancet Diabetes \& Endocrinology, 8(5), 363-365.

Pinho, J. C., \& Prange, C. (2016). The effect of social networks and dynamic internationalization capabilities on international performance. Journal of World Business, 51(3), 391-403. https://doi.org/10.1016/j.jwb.2015.08.001

Porges, S. W. (2003). The polyvagal theory: Phylogenetic contributions to social behavior. Physiology \& behavior, 79(3), 503-513. https://doi.org/10.1016/S0031-9384(03)00156-2

Saam, Z. (2013). Psikologi keperawatan.

Schinke, S. P., Fang, L., \& Cole, K. C. (2008). Substance use among early adolescent girls: Risk and protective factors. Journal of Adolescent Health, 43(2), 191-194. https://doi.org/10.1016/j.jadohealth.2007.12.014

Utari, W., \& Arneliwati, N. R. (2014). Pengetahuan Keluarga Tentang Infeksi Saluran Pernapasan Akut (ISPA). $J$ Online Mhs Progr Stud Ilmu Keperawatan.

Wu, H. K., Lee, S. W. Y., Chang, H. Y., \& Liang, J. C. (2013). Current status, opportunities and challenges of augmented reality in education. Computers \& education, 62, 41-49. https://doi.org/10.1016/j.compedu.2012.10.024 